\title{
CALCULATION MODEL OF A COMPLEX-STRESSED REINFORCED CONCRETE ELEMENT UNDER TORSION WITH BENDING
}

\author{
Nikolay I. Karpenko ${ }^{1,2}$, Vladimir I. Kolchunov ${ }^{2,3}$, Vitaly I. Kolchunov ${ }^{2,3}$, \\ Vladimir I. Travush ${ }^{1,4}$ \\ ${ }^{1}$ Russian Academy of Architecture and Construction Sciences Russian Federation, Moscow, Russia \\ ${ }^{2}$ Research Institute of Building Physics of Russian Academy of Architecture and Construction Sciences, Moscow, Russia \\ ${ }^{3}$ South-West State University, Kursk, Russia, \\ ${ }^{4}$ CJSC "City Calculation Institute of Residential and Public Buildings", Moscow, Russia
}

\begin{abstract}
The article presents the methodology and principles of creating calculation models for reinforced concrete structures operating in conditions of complex resistance. A block calculation model of reinforced concrete bar structures in torsion with bending is presented. This model consists of a support block formed by a spatial crack and a compressed zone of concrete closed on it and a second block formed by a vertical section running perpendicular to the longitudinal axis of a reinforced concrete element along the edge of the compressed zone closing the spatial spiral. Cases are considered when the torque effect has the greatest influence on the stress-strain state of structures. In this case, the following forces are taken into account as the calculated forces in the spatial section: normal and tangential forces in the concrete of the compressed zone; components of axial and shear forces in the reinforcement crossed by a spatial crack. A feature of the proposed calculation model is that it considers independently of each other the strength of an element in spatial sections passing along a spatial crack, and the strength of an element between spatial cracks. The spatial section is formed by a crack located on three sides of the element and a compressed zone located on the fourth side and closing the ends of the spiral crack. In this case, the compressed zone, depending on the ratio of the bending and torque moments, can be located along the horizontal and vertical (lateral) edges of the element. The governing equations are written in the form of static equations for the adopted calculation cross-sections and a closed-loop system that unites them, written as a function of many variables with Lagrange multipliers $\lambda_{i}$. On the basis of the constructed function for all the variables included in it, an additional non-decaying system of equations has been compiled, from which follows a dependence that allows finding the projection of a dangerous spatial crack.
\end{abstract}

Keywords: reinforced concrete, calculation model, torsion with bending, spatial crack, complex stress state.

\section{РАСЧЕТНАЯ МОДЕЛЬ СЛОЖНОНАПРЯЖЕННОГО ЖЕЛЕЗОБЕТОННОГО ЭЛЕМЕНТА ПРИ КРУЧЕНИИ С ИЗГИБОМ}

\author{
Н.И. Карпенко, , Вл. И. Колчунов ${ }^{2,3}$, В.И. Колчунов,, В.И. Травуш ${ }^{1,4}$ \\ ${ }^{1}$ Российская академия архитектуры и строительных наук Российская Федерация, г. Москва, Россия, \\ ${ }^{2}$ Научно-исследовательский институт строительной физики РААСН Российская Федерация, г. Москва, Россия, \\ ${ }^{4}$ Юго-Западный государственный университет, г. Курск, Россия, \\ ${ }_{4}^{4}$ ЗАО «Городской проектный институт жилых и общественных зданий», г. Москва, Россия
}

\begin{abstract}
Аннотация. Изложена методология и принципы создания расчетных моделей, железобетонных конструкций, работающих в условиях сложного сопротивления. Приведена блочная расчетная модель железобетонных стержневых конструкций при кручении с изгибом, состоящая из приопорного блока образованного пространственной трещиной и замыкаемой на нее сжатой зоной бетона и второго блока, образуемого вертикальным сечением, проходящим перпендикулярно к продольной оси железобетонного элемента по краю сжатой зоны, замыкающей пространственную спиралеобразную трещину. Рассмотрены случаи, когда наибольшее влияние на напряженнодеформированное состояние конструкций оказывает действие крутящего момента. При этом в качестве расчетных усилий в пространственном сечении учитываются: нормальные и касательные усилия в бетоне сжатой зоны; составляющие осевых и нагельных усилий в рабочей арматуре, пересекаемой пространственной трещиной. Осо-
\end{abstract}


бенностью предлагаемой расчетной модели является то, что в ней рассматриваются независимо друг от друга прочность элемента по пространственным сечениям, проходящим по пространственной трещине, и прочность элемента между пространственными трещинами. Пространственное сечение образуется трещиной, располагающейся по трем сторонам элемента, и сжатой зоной, располагающейся по четвертой стороне и замыкающей концы спиральной трещины. При этом сжатая зона, в зависимости от соотношения изгибающего и крутящего моментов, может располагаться по горизонтальным и вертикальным (боковым) граням элемента. Разрешающие уравнения составлены в виде уравнений статики для принятых расчетных сечений и объединяющей их замкнутой системы, записанной в виде функции многих переменных с множителями Лагранжа $\lambda_{i}$. На основе построенной функции по всем входящим в нее переменным, составлена дополнительная не распадающихся система уравнений, из которой следует зависимость, позволяющая находить проекции опасной пространственной трещины.

Ключевые слова: железобетон, расчетная модель, кручение с изгибом, пространственная трещина, сложное напряженное состояние.

\section{INTRODUCTION}

There is a whole class of reinforced concrete structures (central load-bearing core of highrise buildings, beams for various purposes with side consoles, inclined arches, L-shaped frames of various types, etc.), in which the lack of consideration of torsion in the calculations can lead to a decrease in their reliability, and in extreme cases, and to the collapse of individual elements of structures and even the entire object. Over the past few years, a number of domestic and foreign studies have been carried out on this topic devoted to the development and experimental verification of new generation calculation models for certain types of complex resistance, which most fully reflect the features of their deformation, cracking and failure with complex resistance, including torsion with bending [1-10, 11-15]. However, the solution of the problem of complex resistance of reinforced concrete, despite these and other works of the considered direction, is still fragmentary, and most importantly, it does not have a reliable experimental justification.

Therefore, a critical analysis, development and substantiation of general calculation models of complex resistance of reinforced concrete, as close as possible to the real work of reinforced concrete structures under a complex stress state, is an urgent task. This is especially true of structures made of high-strength reinforced concrete and fiberreinforced concrete, the specificity of deformation of which under the considered stress state has significant features, and their calculation using traditional models of reinforced concrete does not reflect the stress-strain state of structures made of such materials.

Analysis of domestic and foreign models of deformation of reinforced concrete with cracks most often used in modern software systems shows that the calculation of reinforced concrete structures for the limit states of the second group is performed most often using the criteria for achieving the principal stresses or principal deformations of concrete of their limit values [3-9]. However, an analysis of experimental studies of the last two to three decades [17-21] shows that such criteria reflect the appearance of only dispersed (regular) cracks in reinforced concrete structures. Completely different criteria are needed when modeling the appearance and development of single discrete cracks in reinforced concrete. Here, as shown by experimental studies $[1-4,17,18,20]$, the main role is played by the concentration of deformations in places of change in geometric dimensions, in zones of concentration of force and deformational actions, zones of cross-media concentration [16, 22], cracking in structures made of high-strength reinforced concrete and fiber-reinforced concrete, etc.

An important issue in the practice of research and calculation of reinforced concrete structures in modeling the stress state remains the issue of the correctness of the accepted calculation models as close as possible to the real work of reinforced concrete structures [23]. Problems related to the 
fundamental physical foundations of reinforced concrete deformation and their experimental substantiation, deformational diagrams of concrete and reinforcement in the zones of single cracks and, accordingly, the quantitative values of the width of the opening of such cracks cannot be determined on the basis of traditional deformational models of reinforced concrete built on imperfect hypotheses of the theory of reinforced concrete, in particular, hypotheses about the work of tensile concrete between cracks and above a crack are very conditional.

In connection with the above, some possible directions of development of the modern theory of reinforced concrete are formulated.

- methodology and basic principles for creating of calculation models, reinforced concrete structures operating in conditions of complex resistance and a deformational model of a complex stressed state of reinforced concrete in torsion with bending, as well as its experimental justification. At the same time, the following directions in solving the formulated research goal are considered:

- peculiarities of solving problems of the theory strength, crack resistance and stiffness of reinforced concrete under complex stress state;

- new patterns of crack resistance and deformability of reinforced concrete structures;

- proposals for the construction of physical and calculation models of the resistance of reinforced concrete of a new generation and the modernization of existing hypotheses of the theory of reinforced concrete;

- construction of a calculation model of reinforced concrete deformation with complex resistance bending with torsion;

- experimental substantiation of the deformational model of reinforced concrete with complex resistance.

- features of solving problems of the theory of strength, crack resistance and stiffness of reinforced concrete in a complex stressed state.

Conducted in the last decade, experimental and theoretical studies of complexly stressed reinforced concrete structures, for example $[7,11-$ $13,21]$, including the authors of this publication
$[1-4,8-10]$, show that the criteria used in the calculation models of the criteria for achieving the principal stresses or principal deformations of concrete of their limiting values reflect the appearance and development of only a network of regular cracks in reinforced concrete, for which they were actually formulated.

When solving such problems, as again the accumulated experience of experimental studies on a new basis $[1-4,13,17-21]$ shows, the concentration of deformations at the points of change in geometric dimensions in the zones of concentration of force and deformational actions, in the zones of the so-called crossmedia concentration in two-layer composite and monolithic structures, in structures made of high-strength concrete and in other cases where the formation of discrete cracks is possible. It is especially important to take into account such a concentration for high-strength reinforced concrete and fiber-reinforced concrete, when the formation of single cracks and the deformational effect most significantly affect the relative mutual displacements of concrete and reinforcement, the assessment of the crack opening width and the stiffness of the structure. Methods for modeling this type of cracks have not yet been developed. The general methodology for solving the problems of crack resistance, stiffness and strength of complexly stressed reinforced concrete for the limiting states of the first and second groups in this formulation can be presented in the form of a level diagram (Figure 1).

In accordance with this scheme, the solution to the problem of complex resistance of reinforced concrete is built on a unified methodological basis for the limiting states of the first and second groups. Contradictory in the theory of reinforced concrete is the statement about the work of tensile concrete between the crack and above the crack. Many effects associated with this phenomenon require clarification of their physical nature. There is a need to harmonize the experimental data obtained at one time using a microscope, and in recent years, in connection with the rapid development of measurement technologies and 
instrumental base, digital video cameras, which provide fixation of development and opening in parts of a millisecond with an accuracy of 0.001 $\mathrm{mm}$, up to $0.001 \mathrm{~mm}$, and their theoretical values calculated according to the theory of the existing calculation apparatus for reinforced concrete.
Moreover, when solving the problems of stiffness of reinforced concrete elements with dispersed cracks, the traditional model of V.I. Murashev in one or another of its modifications. Meanwhile, as shown in $[8,17,18,22]$, the distance between the cracks with increasing load remains constant only
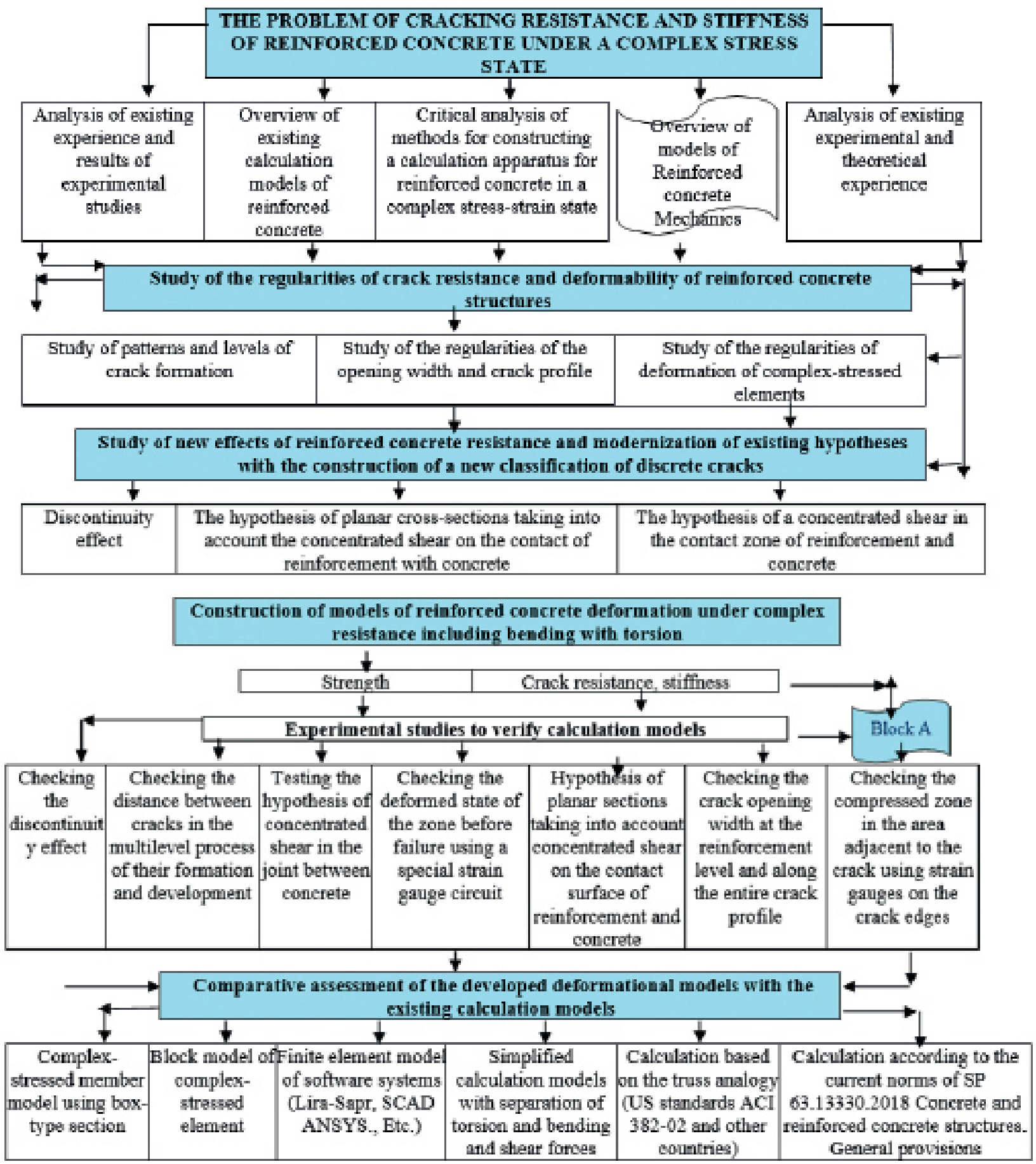

Figure 1. General level scheme for solving the problem of stiffness, crack resistance and strength of reinforced concrete for limiting states 
until the appearance of a new crack. Analysis of the deformation diagram of tensile concrete, together with the nature of the surface warping, confirmed by extensive experimental material, shows that the nature of the deformation diagram of reinforcement changes qualitatively with increasing load(Figure 2.). a)

b)

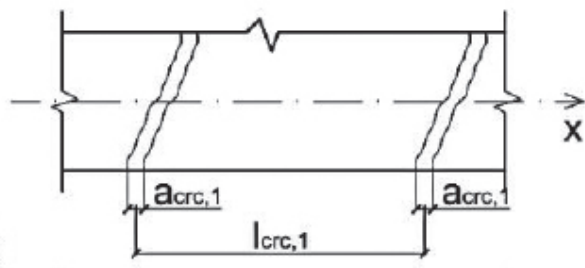

c)

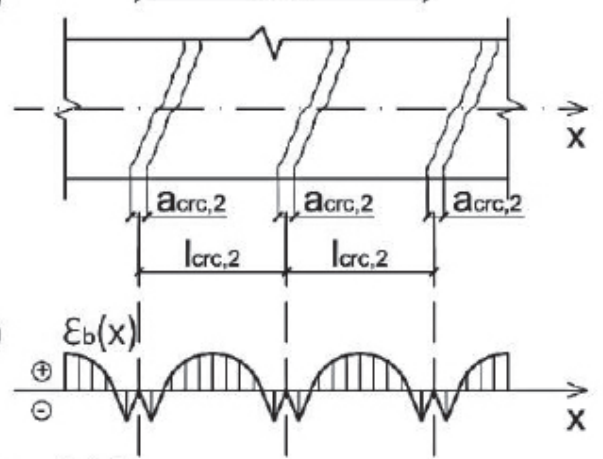

d)

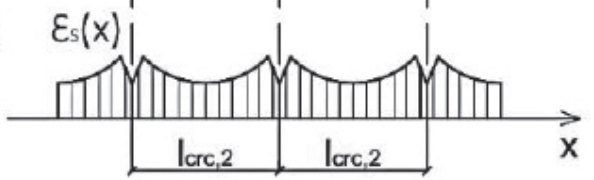

e)

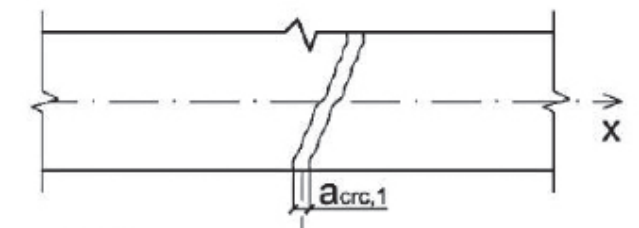

f) $\varepsilon_{b}(x)$

g)

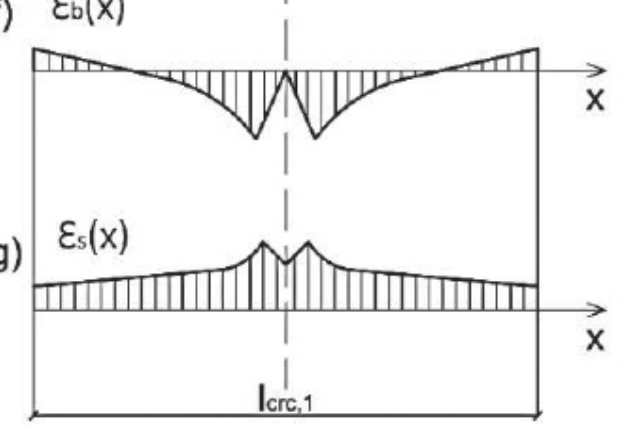

Figure 2: Level picture of cracking in a complexly stressed reinforced concrete element made of usual ( $a-d)$ and high-strength (e-g) reinforced concrete

In areas adjacent to cracks, reinforcement deformations begin to decrease and even change sign. Deformations in the middle of the section increase. It is not always correct to use software systems in studies of structures made of highstrength reinforced concrete, in which traditional physical models built for usual reinforced concrete are used to assess the limiting states of the second group, with averaging deformations for concrete and reinforcement. Meanwhile, the experimental studies of structures made of highstrength reinforced concrete and cracks carried out in recent years show the need to take into account the deformation effect in the crack $[6$, $16,22]$. It is especially important to take into account such an effect for single cracks, when the deformational effect most significantly affects the relative mutual displacements of concrete and reinforcement, the assessment of the crack opening width and the stiffness of the structure. Experimental studies of structures made of fiberreinforced concrete carried out in recent years, for example [1-4], have shown that in structures made of such materials, a qualitatively different nature of deformation and cracking is observed. In these tests, it was found that the pattern of cracks in a reinforced concrete beam made of usual and high-strength reinforced concrete is qualitatively different. In a usual concrete structure, a whole network of cracks forms in the tension zone. Moreover, as the load increases, new cracks $\left(a_{c r c, 2}\right)$ are added to the already formed cracks at the first stage of cracking (cracks $a_{c r c, 1}$ ) at higher stages of loading and, accordingly, the level distances between the cracks $l_{c r c, 1}, l_{c r c, 2}$ change (see Figure 2.). 
In structures made of high-strength concrete, as a rule, single cracks are formed. The nature of the deformation diagrams of concrete and reinforcement in the zone of such cracks and, accordingly, the quantitative values of the width of the opening of such cracks cannot be determined on the basis of the traditional deformation model of reinforced concrete deformation.

The solution of the indicated problems of crack resistance and stiffness of reinforced concrete under a complex stress state at the first level is undoubtedly associated with a deep critical analysis of the existing calculation models of the theory of reinforced concrete, experience and results of experimental studies, including those carried out using a laboratory base of a new generation (see Figure 2 ).

At the second and third levels, it is required to study the physical laws of the deformability and crack resistance of reinforced concrete elements under various types of stress state and to study new effects of reinforced concrete resistance, including the formation of discrete cracks in high-strength reinforced concrete.

The next level in the hierarchy of solving the considered problem is the construction of calculation models of a new generation that most fully reflect physical phenomena under the force and medium resistance of reinforced concrete, including under special actions, and their experimental verification using more advanced equipment and measuring instruments for the investigated parameters.

The most important final level for assessment the effectiveness of solving the considered problems and the reliability of the obtained solutions is a comparative assessment of the developed deformation models of the theory of complex resistance of reinforced concrete with the existing calculation models for the limiting states of the first and second groups.

IMPLEMENTATION OF THE GENERAL SCHEME FOR BENDING WITH TORSION (experiment comparison with norms).

Using the methodology of the presented general level scheme for solving the problem of stiffness, crack resistance and strength of reinforced concrete, the construction of a calculation model of a complexly stressed reinforced concrete element undergoing torsion with bending is considered. The proposed calculation model for analyzing the stress-strain state of reinforced concrete elements with complex resistance - torsion with bending is based on the accepted in domestic practice in the works of A.A. Gvozdev [24], N.I. Karpenko [5,6], V1.I. Kolchunov [8-10], Fedorov V.S. [25], V.I. Morozov [7] and other scientists approach, which is that the strength of an element in spatial sections passing through a spatial crack and the strength of an element between spatial cracks are considered independently of each other. The spatial section is formed by a crack located on three sides of the element and a compressed zone located on the fourth side and closing the ends of the spiral crack. In this case, the compressed zone, depending on the ratio of the bending and torques, can be located along the horizontal and vertical (lateral) edges of the element. The calculation is based on the equilibrium of the moments of external and internal forces in a spatial section. In this case, in the spatial section, the forces in the longitudinal and transverse reinforcement are taken into account, crossing the spatial section at the face opposite to the compressed zone. The forces in the longitudinal and transverse reinforcement are entered into the calculation with their calculation resistances at a certain ratio established from the analysis of experimental data.

The compilation of equations requires some explanation. The upper, lower and lateral longitudinal reinforcement (in the presence of multi-tiered reinforcement), in Figure 3, a (Scheme A) and Figure 3, a (Scheme B) are conventionally not shown in order to eliminate the bulkiness of the image. In conditions of equilibrium, the stresses arising in the noted reinforcement are taken into account. The only exception is the equation of equilibrium of the moments of internal and external forces acting in section I-I relative to the axis perpendicular to this section and passing through the point of application of the resultant forces in the compressed zone $\left(T_{b, I}=0\right)$. 
When considering the normal section I - I (III III) and the spatial section $\mathrm{k}$, the following are taken into account: the limiting support reaction $R_{\text {sup }}$; the height of the compressed zone of concrete in a normal section $x_{B, 1}$; coefficient for determining the lateral force $\gamma_{Q, t}$; stress of longitudinal reinforcement in normal section $\sigma_{s, I} ;$ stress in the reinforcement at the side faces of the section of the structure in the spatial section $\sigma_{s, s i d, k}$; the height of the compressed zone of the spatial section $x_{B, k}$; linear force in transverse reinforcement located at the side, top and bottom edges $q_{s w, \sigma, u p}, q_{s w, \sigma}, q_{s w, l e f}$; normal stresses in concrete $\sigma_{b u, x, I}$; components of axial stresses in the working reinforcement crossed
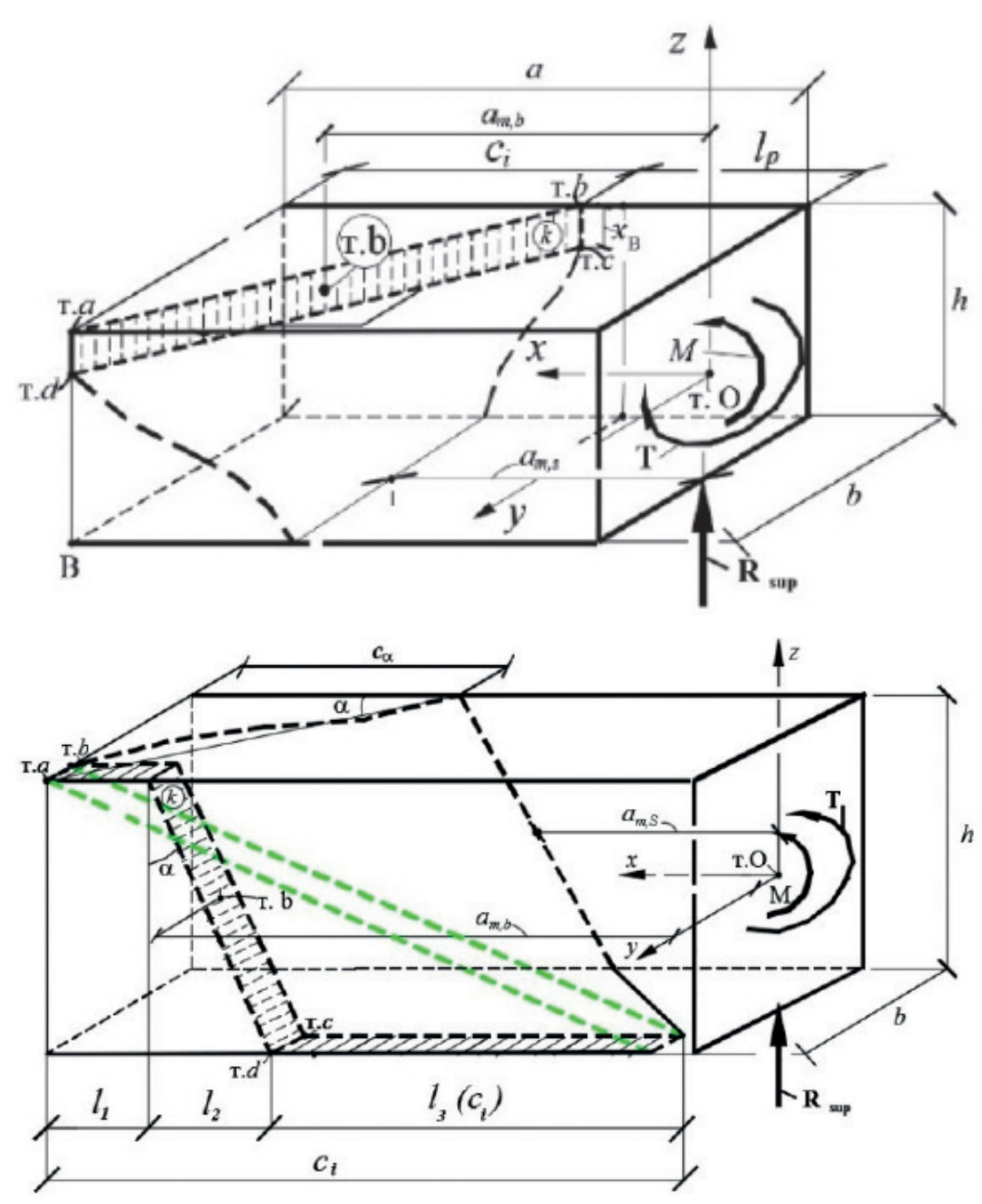

by a spatial crack $\sigma_{s, u p}, \sigma_{s c, u p}, \sigma_{s, d}, \sigma_{s c, d} ;$ shear forces in concrete with the completeness coefficients of their diagrams $\omega_{1} \tau_{y z}, \omega_{2} \tau_{z}$; components of the thrust forces in the working reinforcement crossed by the spatial crack $k$, as well as the lengths of the projections of the spatial crack sections onto the horizontal axis $l_{1}, l_{2}, l_{3}\left(c_{i}\right)$.

In the spatial section k-k for block 2, cut off by a complex section, passing along a spiral spatial crack and along a broken section of the compressed zone, all reinforcement falling into this section is taken into account. In this case, in the compressed upper longitudinal reinforcement, cut off by sections I - I and III - III, the nagel effect is not taken into account, and in the rest of the longitudinal and transverse reinforcement, the components of the nagel effect are taken into account.

The need to use a complex broken section of the compressed zone of concrete is due to the fact that, according to experimental data, its destruction occurs in a certain volume, located not along the entire length between points $a$ and $b$ (see Figure 3.1), but only in a certain volume located in the middle part. In this case, the failure occurs in the middle part not along the line $a b$, but at an angle close to $45^{\circ}$ to the upper edge of the reinforced concrete structure, which predetermined the direction of the middle part of the broken section, where the ultimate stress-strain state is reached.

In the areas of the compressed zone located at the edges of the broken section, the stress-strain state varies from sections I - I and III - III to the middle zone according to linear dependences, respectively. In this case, it is assumed that the height of the 
compressed zone decreases with an increase in the bending moment.

The lateral surfaces of the broken section in compressed concrete (see Figure $3 \mathrm{~b}$ ) coincide with the planes of the axis or "smeared" plane of the working longitudinal reinforcement.

In this case, angular reinforcement when crossing by a broken section is considered to be located on the left for section I-I and on the right for section III - III. Thus, it is intersected by planes I- I, III - III, respectively, at the end sections of a complex broken section (see Figure 3 - scheme A and Figure 4 - scheme B). Diagrams of the distribution of forces from torques in the compressed and extended zones in the middle section I - I using the example of case B are shown in Figure 4.
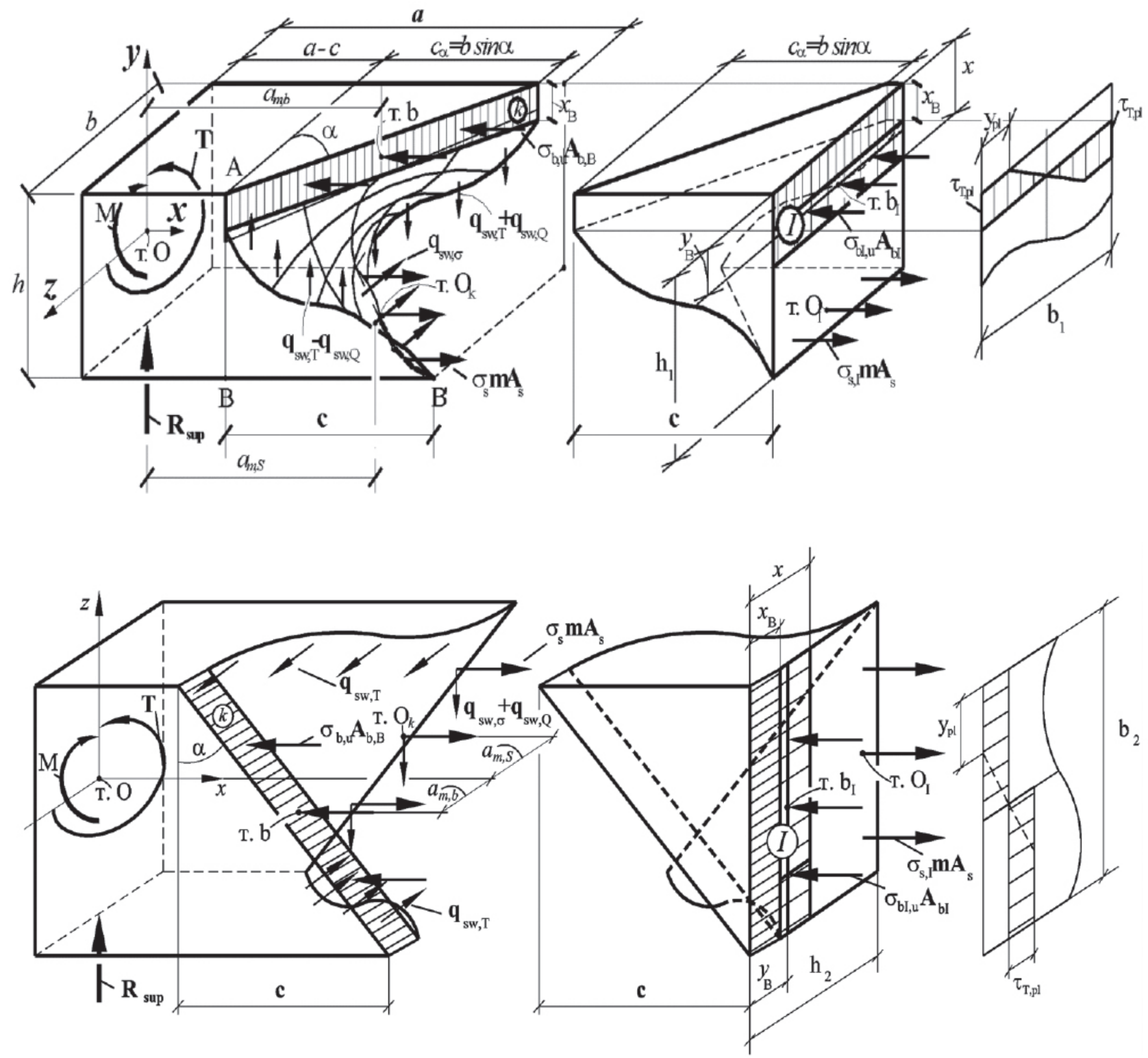
The general solution of the considered problem is constructed as follows. The statics equations are written for the calculation sections I - I and the spatial section $\mathrm{k}-\mathrm{k}$ adopted in the block model. In this case, when projecting the stress components in the $\mathrm{k}$ plane onto the I - I plane, a parameter $\varphi_{10, *}$ is introduced that takes into account such a projection of the stress components.

Also introduced: a parameter $K_{\mathrm{M}}$ that takes into account the static loading scheme from the standpoint of additional bending moments along the length of the bar; parameter $K_{\mathrm{pr}, \mathrm{M}}$ that takes into account the relationship between the generalized support reaction $R_{\text {sup }}$ and the bending moment $M$ and a static-geometric parameter $\varphi_{y}\left(x_{b}, x\right)=$ const that takes into account the location of the center of gravity of the compressed zone of concrete in section I-I, where the compressive stress diagram is rectangular in the area $x_{B}$ and triangular in the area $\left.x-x_{B}\right)$.

As a result, from the equilibrium equation of the projections of all forces acting in section I-I on the $x$ axis, the height of the compressed concrete zone $x$ in this section $\left(\sum X=0\right)$ is determined, from the equation of the sum of torques relative to the point of application of the resultant forces in compressed concrete $b_{I}\left(\sum T_{b, I}=0\right)$ we obtain a value $x \cdot \lambda_{I I}$ characterizing the height of the compressed zone, where the shear stresses from the torque reach the yield point, and from the hypothesis of planar cross-sections, the average value of stresses in the reinforcement $\sigma_{s, m, I}$ is found.

Equations are written in a similar way for the spatial section $k-k$ formed by a spiral-shaped crack and a vertical section passing through the compressed zone of concrete through the end of the front of the spatial crack (see Figure 4).

The missing unknowns of the considered calculation model are determined by compiling a function of many variables with Lagrange multipliers $\lambda_{i}$ for mechanical systems of the form $F\left(R_{\text {sup }}, x, x_{B}, \gamma_{Q, t}, \gamma_{T, k}\right.$, $\sigma_{s, l}, \sigma_{S, k}, q_{s w, r i g}, q_{s w, l e p} q_{s w, \sigma}, c, \lambda_{1}, \lambda_{2}, \lambda_{3}, \lambda_{4}, \lambda_{5}, \lambda_{6}, \lambda_{7}, \lambda_{8}$, $\left.\lambda_{q}\right)$ : and equating to zero its partial derivatives with respect to all variables included in it. As a result, an additional system of equations is obtained for determining the unknowns.

\section{EXPERIMENTAL SUBSTANTIATION OF THE PROPOSED CALCULATION MODEL} of the strength of a complex stressed reinforced concrete element in torsion with bending was carried out by conducting a series of experimental studies of reinforced concrete structures. Thus, in [1], it was found that for reinforced concrete structures of square section made of high-strength concrete of class B100 during torsion with bending, as a rule, there is only one main crack (the fragile structure of high-strength concrete contributes to such concentration), along which failure occurs. For the box-shaped section, several cracks took place, from which the one along which the failure occurs. At the steps preceding failure, this crack begins to prevail over the rest and has a maximum opening width. Such features of cracking are fully consistent with the hypotheses underlying the calculation model for high-strength concrete.

Based on experimental studies of reinforced concrete structures made of high-strength concrete $[2,4]$ and fiber-reinforced concrete [3] of circular crosssection, data on the complex stress-strain state in the studied regions of resistance were obtained, such as: values of the generalized load of cracking, and failure, its level relative to the ultimate load; the distance between cracks at different levels of cracking (two or three levels are usually formed before the failure occurs); width of crack opening at the level of the axis of the working reinforcement, at a distance of two diameters from the axes of the reinforcement and along the entire profile of the crack at various stages of loading; coordinates of points $(x ; y ; z)$ of formation of spatial cracks; schemes of the formation, development and opening of cracks in reinforced concrete structures during torsion with bending, which confirmed their satisfactory agreement with the results of the calculation according to the considered calculation model.

\section{CONCLUSIONS}

1. A general calculation model of the complex resistance of reinforced concrete structures in 
torsion with bending is proposed. The model includes a support block formed by a spatial crack and a compressed zone of concrete closed on it, - a spatial section $k$ and a second block formed by a vertical section I-I, passing perpendicular to the longitudinal axis of the reinforced concrete element along the edge of the compressed zone closing the spatial crack. In this case, option A of the calculation model A is used for a spiral-shaped spatial crack, option B - for a spatial X-shaped crack.

2. In the consideration of the general model, the first and second cases are accepted, when of the three external influences during torsion with bending $(Q, M, T)$, the torque $\mathrm{T}$ exerts the greatest influence on the stress-strain state of the structure. 3 . The resolving equations of the proposed block model are composed in the form of static equations for the adopted sections and a closed-loop system that unites them, written in the form of a function of many variables with Lagrange multipliers $\lambda_{i}$. On the basis of the constructed function for all the variables included in it, an additional system of equations has been compiled, from which a dependence follows, which makes it possible to find the projections of a dangerous spatial crack. 4. The proposed calculation model was experimentally confirmed by tests of a fairly representative group of reinforced concrete structures made of ordinary and high-strength concrete and fiber-reinforced concrete, carried out with the participation of the authors and other researchers.

\section{REFERENCES}

1. Travush V.I., Karpenko N.I., Kolchunov V.I., Kaprielov S.S., Dem'yanov A.I., Konorev A.V. Rezul'taty eksperimental'nyh issledovanij konstrukcij kvadratnogo i korobchatogo sechenij iz vysokoprochnogo betona pri kruchenii s izgibom [Results of experimental studies of structures of square and box sections made of highstrength concrete in torsion with bending] //
Stroitel'stvo i rekonstrukciya. 2018. № 6 (80). Pp. 32-43.

2. Travush V.I., Karpenko N.I., Kolchunov V.I., Kaprielov S.S., Demyanov A.I., Bulkin S.A., Moskovtseva V.S. Results of experimental studies of high-strength fiber reinforced concrete beams with round cross-sections under combined bending and torsion //Structural Mechanics of Engineering Constructions and Buildings. - 2020. - T. 16. - №. 4. - C. 290-297.

3. Travush V.I., Karpenko N.I, Kolchunov Vl. I., Kaprielov S.S., Dem'yanov A.I., Bulkin S.A., Moskovceva V.S. Rezul'taty eksperimental'nyh issledovanij slozhno-napryazhennyh balok kruglogo poperechnogo secheniya iz vysokoprochnogo fibrozhelezobetona [Results of experimental studies of high-strength fiber reinforced concrete beams with round cross-sections under combined bending and torsion] // Stroitel'naya mekhanika inzhenernyh konstrukcij i sooruzhenij. 2020.t.16, №4. Pp. 290-297.

4. Travush V.I., Karpenko N.I., Kolchunov Vl. I., Kaprielov S.S., Dem'yanov A.I., Konorev A.V. Osnovnye rezul'taty eksperimental'nyh issledovanij zhelezobetonnyh konstrukcij iz vysokoprochnogo betona V100 kruglogo i kol'cevogo sechenij pri kruchenii s izgibom [The main results of experimental studies of reinforced concrete structures made of high-strength concrete B100 of circular and circular sections in torsion with bending] // Stroitel'naya mekhanika inzhenernyh konstrukcij i sooruzhenij. 2019.t.15, №1. Pp. 51-61.

5. Karpenko N.I., CHistova T.P. ZHestkost' i treshchinostojkost' elementov pri sovmestnom dejstvii izgiba i krucheniya [Rigidity and crack resistance of elements under the combined action of bending and torsion] / V kn.: Predel'nye sostoyaniya elementov zhelezobetonnyh konstrukcij. M.: Strojizdat, 1976. Pp. 154-169.

6. Karpenko N.I. Teoriya deformirovaniya zhelezobetona s treshchinami [The theory 
of deformation of reinforced concrete with cracks]. - M.: Strojizdat, 1976. 204 p.

7. Morozov V.I., Bahotskij I.V. K raschetu fibrozhelezobetonnyh konstrukcij, podverzhennyh sovmestnomu vozdejstviyu krucheniya s izgibom [To the calculation of fiber-reinforced concrete structures subject to joint action of torsion with bending] // Sovremennye problemy nauki i obrazovaniya. 2013. № 5. P. 109.

8. Kolchunov Vl. I., Safonov A.G. Postroenie rascheta zhelezobetonnyh konstrukcij na kruchenie s izgibom [Calculation of reinforced concrete structures for torsion with bending] // Izvestiya Orlovskogo gosudarstvennogo tekhnicheskogo universiteta. Seriya «Stroitel'stvo. Transport». Orel: Orel GTU. 2008. №4. Pp. 7-13.

9. Kolchunov, V.I., Dem'yanov, A.I. The modeling method of discrete cracks in reinforced concrete under the torsion with bending. Magazine of Civil Engineering. 2018. 81(5). Pp. 160-173. doi: 10.18720/ MCE.81.16.

10. Kolchunov Vl.I., Dem'yanov A.I., Naumov N.V. The Second Stage of the Stress-Strain State of Reinforced Concrete Constructions under the Action of Torsion with Bending (Theory) International science and technology conference "FarEastCon-2019" IOP Conf. Series: Materials Science and Engineering 753 (2020) 032056 IOP Publishing doi:10.1088/1757-899X/753/3/032056

11. Ilker Kalkan, Saruhan Kartal. Torsional Rigidities of Reinforced Concrete Beams Subjected to Elastic Lateral Torsional Buckling. International Journal of Civil and Environmental Engineering. 2017. Vol. 11. No.7. Pp. 969-972.

12. Nahvi H., Jabbari M. Crack detection in beams using experimental modal data and finite element model. International Journal of Mechanical Sciences. 2005. Vol. 47. Pp.1477-1497.

13. Adheena Thomas, Afia S Hameed. An Experimental Study On Combined Flexural
And Torsional Behaviour Of RC Beams. International Research Journal of Engineering and Technology. 2017. Vol. 04. Issue 05. Pp. 1367-1370.

14. Mostofinejad D., Talaeitaba S.B. Nonlinear Modeling of RC Beams Subjected to Torsion using the Smeared Crack Model // Procedia Engineering 14 (2011) 1447-1454. Elsevied Ltd. 2011. Pp.1447-1454.

15. G. Klein, G. Lucier, S. Rizkalla, P. Zia and H. Gleich. Torsion simplified: a failure plane model for desigh of spandrel beams // ACI Concrete International Journal, February 2012. Pp.1-19.

16. Bondarenko V.M., Kolchunov V.I. Raschetnye modeli silovogo soprotivleniya zhelezobetona [Calculation models of the strength resistance of reinforced concrete]: Monografiya. - M.: Izdatel'stvo ASV, 2004. $474 p$

17. Dem'yanov A.I., Sal'nikov A.S., Kolchunov VI.I. Eksperimental'nye issledovaniya zhelezobetonnyh konstrukcij pri kruchenii s izgibom $i$ analiz ih rezul'tatov [Experimental studies of reinforced concrete structures in torsion with bending and analysis of their results] // Stroitel'stvo i rekonstrukciya. 2017. №4(72). P. 17-26.

18. Dem'yanov A.I., Pokusaev A.A., Kolchunov V.I. Eksperimental'nye issledovaniya zhelezobetonnyh konstrukcij pri kruchenii s izgibom [Experimental studies of reinforced concrete structures in torsion with bending] // Stroitel'stvo i rekonstrukciya. 2017. №5(73). Pp. 5-14.

19. Dem'yanov A.I., Kolchunov V.I., Pokusaev A.A. Eksperimental'nye issledovaniya deformirovaniya zhelezobetonnyh konstrukcij pri kruchenii s izgibom [Experimental studies of the deformation of reinforced concrete structures during torsion with bending] // Stroitel'naya mekhanika inzhenernyh konstrukcij i sooruzhenij. 2017. №6. Pp. 37-44.

20. Dem'yanov A.I., Naumov N.V., Kolchunov Vl.I. Nekotorye rezul'taty eksperimental'nyh 
issledovanij sostavnyh zhelezobetonnyh konstrukcij pri kruchenii s izgibom [Some results of experimental studies of composite reinforced concrete structures in torsion with bending] // Stroitel'stvo i rekonstrukciya. 2018. №5(79). Pp. 13- 23.

21. CHistova T.P. Eksperimental'noe issledovanie deformacij obychnyh zhelezobetonnyh elementov korobchatogo i sploshnogo pryamougol'nogo secheniya pri chistom kruchenii [Experimental study of deformations of conventional reinforced concrete elements of box-shaped and solid rectangular crosssection with pure torsion]. V sb. «Prochnost' i zhestkost' zhelezobetonnyh konstrukcij» pod redakciej S.A. Dmitrieva i S.M. Krylova. M., Strojizdat, 1971.

22. Kolchunov V.I., Kolchunov VI.I., Fedorova N.V. Deformacionnye modeli zhelezobetona pri osobyh vozdejstviyah [Deformacionnye modeli zhelezobetona pri osobyh vozdejstviyah] // Promyshlennoe i grazhdanskoe stroitel'stvo. 2018. № 8. Pp. 54-60.

23. Kolchunov Vl. I., Fedorov V.S. Ponyatijnaya ierarhiya modelej $\mathrm{v}$ teorii soprotivleniya stroitel'nyh konstrukcij [Conceptual hierarchy of models in the theory of resistance of building structures] // Promyshlennoe i grazhdanskoe stroitel'stvo. 2020. №8. S. 1623. DOI: 10.33622/0869-7019.2020.08.16-23.

24. Gvozdev A. A. Metod predel'nogo ravnovesiya $\mathrm{v}$ primenenii $\mathrm{k}$ raschetu zhelezobetonnyh konstrukcij [The ultimate equilibrium method as applied to the calculation of reinforced concrete structures] // M.: Inzhenernyj sbornik. - 1949. - №. 2. - Pp. 45-47.

25. Fedorov V.S., Kolchunov Vl. I., Pokusaev A.A. Raschet rasstoyaniya mezhdu prostranstvennymi treshchinami i shiriny ih raskrytiya $\mathrm{v}$ zhelezobetonnyh konstrukciyah pri kruchenii s izgibom (sluchaj 2) [Calculation of the distance between spatial cracks and the width of their opening in reinforced concrete structures in torsion with bending (case 2)] // ZHilishchnoe stroitel'stvo. - 2016. - №5. Pp. 16-21.

\section{СПИСОК ЛИТЕРАТУРЫ}

1. Травуш В.И., Карпенко Н.И., Колчунов В.И., Каприелов С.С., Демьянов А.И., Конорев А.В. Результаты экспериментальных исследований конструкций квадратного и коробчатого сечений из высокопрочного бетона при кручении с изгибом // Строительство и реконструкция. 2018. № 6 (80). C. $32-43$.

2. Travush V.I., Karpenko, N.I., Kolchunov, V.I., Kaprielov, S.S., Demyanov, A.I., Bulkin, S.A., Moskovtseva, V.S. Results of experimental studies of high-strength fiber reinforced concrete beams with round cross-sections under combined bending and torsion //Structural Mechanics of Engineering Constructions and Buildings. - 2020. - T. 16. - №. 4. - C. 290-297.

3. Травуш В.И., Карпенко Н.И, Колчунов Вл. И., Каприелов С.С., Демьянов А.И., Булкин С.А., Московцева В.С. Результаты экспериментальных исследований сложно-напряженных балок круглого поперечного сечения из высокопрочного фиброжелезобетона // Строительная механика инженерных конструкций и сооружений. 2020.т. 16, №4. - С. 290-297.

4. Травуш В.И., Карпенко Н.И., Колчунов Вл. И., Каприелов С.С., Демьянов А.И., Конорев А.В. Основные результаты экспериментальных исследований железобетонных конструкций из высокопрочного бетона В100 круглого и кольцевого сечений при кручении с изгибом // Строительная механика инженерных конструкций и сооружений. 2019.т.15, №1. - С. 51-61.

5. Карпенко Н.И., Чистова Т.П. Жесткость и трещиностойкость элементов при совместном действии изгиба и кручения / В кн.: Предельные состояния элементов железобетонных конструкций. М.: Стройиздат, 1976. - С.154-169.

6. Карпенко Н.И. Теория деформирования железобетона с трещинами. - М.: Стройиздат, 1976. 204 с. 
7. Морозов В.И., Бахотский И.В. К расчету фиброжелезобетонных конструкций, подверженных совместному воздействию кручения с изгибом // Современные проблемы науки и образования. 2013. № 5. С. 109.

8. Колчунов Вл. И., Сафонов А.Г. Построение расчета железобетонных конструкций на кручение с изгибом // Известия Орловского государственного технического университета. Серия «Строительство. Транспорт». Орел: Орел ГТУ. 2008. №4. С. 7-13.

9. Kolchunov, V.I., Dem'yanov, A.I. The modeling method of discrete cracks in reinforced concrete under the torsion with bending. Magazine of Civil Engineering. 2018. 81(5). Pp. 160-173. doi: 10.18720/ MCE.81.16.

10. Kolchunov Vl.I., Dem'yanov A.I., Naumov N.V. The Second Stage of the Stress-Strain State of Reinforced Concrete Constructions under the Action of Torsion with Bending (Theory) International science and technology conference "FarEastCon-2019" IOP Conf. Series: Materials Science and Engineering 753 (2020) 032056 IOP Publishing doi:10.1088/1757-899X/753/3/032056

11. Ilker Kalkan, Saruhan Kartal. Torsional Rigidities of Reinforced Concrete Beams Subjected to Elastic Lateral Torsional Buckling. International Journal of Civil and Environmental Engineering. 2017. Vol. 11. No.7. Pp. 969-972.

12. Nahvi H., Jabbari M. Crack detection in beams using experimental modal data and finite element model. International Journal of Mechanical Sciences. 2005. Vol. 47. Pp.1477-1497.

13. Adheena Thomas, Afia S Hameed. An Experimental Study On Combined Flexural And Torsional Behaviour Of RC Beams. International Research Journal of Engineering and Technology. 2017. Vol. 04. Issue 05. Pp. 1367-1370.

14. Mostofinejad D., Talaeitaba S.B. Nonlinear Modeling of RC Beams Subjected to Torsion using the Smeared Crack Model // Procedia Engineering 14 (2011) 1447-1454. Elsevied Ltd. 2011. Pp. 1447-1454.

15. G. Klein, G. Lucier, S. Rizkalla, P. Zia and H. Gleich. Torsion simplified: a failure plane model for desigh of spandrel beams // ACI Concrete International Journal, February 2012. Pp.1-19.

16. Бондаренко В.М., Колчунов В.И. Расчетные модели силового сопротивления железобетона: Монография. - М.: Издательство ACB, 2004. 474c.

17. Демьянов А.И., Сальников А.С., Колчунов Вл. И. Экспериментальные исследования железобетонных конструкций при кручении с изгибом и анализ их результатов // Строительство и реконструкция. 2017. №4(72). С. 17-26.

18. Демьянов А.И., Покусаев А.А., Колчунов В.И. Экспериментальные исследования железобетонных конструкций при кручении с изгибом // Строительство и реконструкция. 2017. №5(73). С. 5-14.

19. Демьянов А.И., Колчунов В.И., Покусаев А.А. Экспериментальные исследования деформирования железобетонных конструкций при кручении с изгибом // Строительная механика инженерных конструкций и сооружений. 2017. №6. С. 37-44.

20. Демьянов А.И., Наумов Н.В., Колчунов Вл. И. Некоторые результаты экспериментальных исследований составных железобетонных конструкций при кручении с изгибом // Строительство и реконструкция. 2018. №5(79). С. 13-23.

21. Чистова Т.П. Экспериментальное исследование деформаций обычных железобетонных элементов коробчатого и сплошного прямоугольного сечения при чистом кручении. В сб. «Прочность и жесткость железобетонных конструкций» под редакцией С.А. Дмитриева и С.М. Крылова. М., Стройиздат, 1971.

22. Колчунов В.И., Колчунов Вл.И., Федорова Н.В. Деформационные модели железобетона при особых воздействиях // 
Промышленное и гражданское строительство. 2018. № 8. С. 54-60.

23. Колчунов Вл. И., Федоров В.С. Понятийная иерархия моделей в теории сопротивления строительных конструкций // Промышленное и гражданское строительство. 2020. №8. C. 16-23. DOI: 10.33622/08697019.2020.08.16-23.

24. Гвоздев А.А. Метод предельного равновесия в применении к расчету железобе- тонных конструкций // М.: Инженерный сборник. - 1949. - №. 2. - С. 45-47.

\section{5. Федоров В.С., Колчунов Вл. И., Покусаев}

А.А. Расчет расстояния между пространственными трещинами и ширины их раскрытия в железобетонных конструкциях при кручении с изгибом (случай 2) // Жилищное строительство. - 2016. - №5. - С. $16-21$.
Nikolay I. Karpenko, Full Member of Russian Academy of Architecture and Construction Sciences, Professor, Dr.Sc., Head of Laboratory of Research Institute for Building Physics, Russian Academy of Architecture and Construction Sciences; Academic Secretary of the Section of Construction Sciences of the Russian Academy of Ar-chitecture and Construction Sciences; 21, Locomotivniy Proezd, Moscow, 127238, Russia, NIISF RAASN; phone: +7(495)482-40-76, fax: +7(495)482-40-60, e-mail: niisf_lab9@mail.ru

Vitaly I. Kolchunov, Full Member of Russian Academy of Architecture and Construction Sciences, Dr.Sc., Professor, Head of Department of unique building and structures, South-Western State University, 94, 50 let Oktyabrya street, Kursk, 305040, Russia phone: +7 (4712) 22-24-61; e-mail: asiorel@mail.ru

Vladimir I. Kolchunov, Dr.Sc., Professor, Department of unique building and structures, South-Western State University, 94, 50 let Oktyabrya street, Kursk, 305040,Russia phone: +7 (910) 317-93-55; e-mail: vlik52@mail.ru

Vladimir I. Travush, Full Member of Russian Academy of Architecture and Construction Sciences, Professor, Dr.Sc.; Vice-Director, Urban planning institute of residential and public buildings (GORPROJECT); Vice-President of the Russian Academy of Architecture and Construction Sciences; 24, Bolshaya Dmitrovka Street, Moscow, 107031, Russia; phone/fax: +7(495)625-79-67, e-mail: travush@mail.ru

Карпенко Николай Иванович, академик РААСН, профессор, доктор технических наук, заведующий лабо- раторией; «Проблемы прочности и качества в строительстве», федеральное государственное бюджетное учреждение «Научно-исследовательский институт строительной физики Российской академии архитектуры и строительных наук»; академик-секретарь Отделения строительных наук Российской академии архитектуры и строительных наук; 127328, Россия, г. Москва, Локомотивный проезд, д. 21, НИИСФ РА-АСН; тел. +7(495)482-40-76, факс: +7(495)482-40-60, e-mail: niisf_lab9@mail.ru

Колчунов Владимир Иванович, доктор технических наук, профессор кафедры «Уникальные здания и сооружения», Юго-Западный государственный университет; 305040, Россия, г. Курск, ул. 50 лет Октября, дом 94; тел .: +7 (910) 317-93-55; e-mail: vlik52@mail.ru

Колчунов Виталий Иванович, академик РААСН, професcop, доктор технических наук, заведующего кафедрой «Уникальные здания и сооружения», Юго-Западный государственный университет; 305040, Россия, г. Курск, ул. 50 лет Октября, дом 94; тел.: +7 (4712) 22-24-61; e-mail: asiorel@mail.ru

Травуш Владимир Ильич, академик РААСН, профессор, доктор технических наук; заместитель генерального директора по научной работе, ЗАО «Городской проектный институт жилых и общественных зданий»; вице-президент Российской академии архитектуры и строительных наук; 105005, Россия, г. Москва, наб. Академика Туполева, д. 15, корп. 15, этаж 5, ГОРПРОЕКТ; тел./факс: +7(495)625-79-67, e-mail: travush@mail.ru 